From Protest to Acquiescence?

Political Movements of the Unemployed 


\section{Also by Paul Bagguley}

RESTRUCTURING: Place, Class and Gender (co-author) 


\title{
From Protest to Acquiescence?
}

\section{Political Movements of the Unemployed}

\author{
Paul Bagguley
}

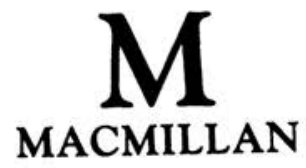


(C) Paul Bagguley 1991

All rights reserved. No reproduction, copy or transmission of this publication may be made without written permission.

No paragraph of this publication may be reproduced, copied or transmitted save with written permission or in accordance with the provisions of the Copyright, Designs and Patents Act 1988, or under the terms of any licence permitting limited copying issued by the Copyright Licensing Agency, 33-4 Alfred Place, London WCIE 7DP.

Any person who does any unauthorised act in relation to this publication may be liable to criminal prosecution and civil claims for damages.

First published 1991

Published by

MACMILLAN EDUCATION LTD

Houndmills, Basingstoke, Hampshire RG21 2XS

and London

Companies and representatives

throughout the world

Edited and typeset by Povey/Edmondson

Okehampton and Rochdale, England

British Library Cataloguing in Publication Data

Bagguley, Paul

From protest to acquiescence? Political movements of the unemployed.

1. Great Britain. Labour movements, history

I. Title

331.80941

ISBN 978-0-333-53478-6 ISBN 978-1-349-21655-0 (eBook)

DOI 10.1007/978-1-349-21655-0 


\section{Contents}

List of Tables and Figures vii

Preface viii

List of Abbreviations $\quad \mathrm{x}$

1 Introduction 1

1.1 The rise of unemployment during the $1980 \mathrm{~s}$

2 Theoretical Approaches To Politics and Unemployment 12

$\begin{array}{lll}2.1 & \text { Introduction } & 12\end{array}$

2.2 Speculative Theories 12

2.3 The neo-Marxist approach: Piven and Cloward 23

2.4 The 'behaviourist' approach: Schlozman and Verba 29

2.5 A British test of Schlozman and Verba: Marshall et al.

2.6 Conclusion 36

3 The Structuring of Political Responses To Unemployment 37

$\begin{array}{lll}3.1 & \text { Introduction } & 37\end{array}$

3.2 The unemployed and the state 38

3.3 Organisational resources $\quad 45$

3.4 Cultural resources 56

3.5 Community as a cultural resource 63

$\begin{array}{ll}3.6 \text { Conclusion } & 70\end{array}$

4 Early Political Movements of The Unemployed 72

4.1 The anti-Poor Law movement 72

4.2 The Land and Labour League 76

4.3 The Social Democratic Federation: 1880-1914 78

4.4 The National Unemployed Workers' Movement 84

4.5 Protest and the changing forms of unemployment relief: $1918-39$ 
4.6 A messianic communism? The organisational and cultural resources of the NUW(C)M

4.7 Gender politics in the NUW(C)M 108

4.8 Conclusion 112

5 Political Movements of the Unemployed in the 1980s

5.1 Introduction 114

5.2 The TUC and centres for the unemployed 116

5.3 The unemployed workers' centre in Brighton 124

5.4 The campaign for a new centre 134

$\begin{array}{ll}5.5 \text { Conclusion } & 139\end{array}$

6 The Experience of Unemployment 141

6.1 Introduction 141

6.2 Perceptions of the disadvantages of unemployment 142

6.3 Perceptions of advantages of unemployment 150

6.4 Experience of the Unemployment Benefit and DHSS offices $\quad 155$

6.5 Views about reasons for high unemployment $\quad 158$

6.6 Conclusion 164

7 Thatcherism, Class Consciousness and the Unemployed

$\begin{array}{lll}7.1 & \text { Thatcherism } & 167\end{array}$

7.2 Class consciousness and the unemployed 178

7.3 The political organisation of the unemployed 187

7.4 Class consciousness amongst the unemployed 191

7.5 Conclusion 200

8 Conclusion 201

Notes 204

$\begin{array}{ll}\text { Bibliography } & 208\end{array}$

$\begin{array}{ll}\text { Index } & 220\end{array}$ 


\section{List of Tables and Figures}

Tables

1.1 Unemployment rates by region and sex: Great Britain, 1985

1.2 Unemployment and vacancies by occupational class and sex: Great Britain, September 1982

1.3 Change in unemployment and unfilled vacancies by sex and occupational class: Great Britain, 1978-1982

3.1 Periodisation of state forms of unemployment relief

3.2 Ideal typical paradigms of political movements of the unemployed

4.1 Membership of working-class organisations amongst the unemployed in selected localities, 1936

4.2 Delegates from women's sections to NUWM Seventh National Congress

Figures

1.1 Total unemployment in Great Britain, 1978-90 (May figures)

3.1 Ideal type of conjuncture of resources favouring mobilisation

3.2 Ideal type of conjuncture of resources blocking mobilisation

4.1 Trade union unemployment, 1870-1912 79

4.2 Unemployment rate, 1921-38 


\section{Preface}

This book began as a D.Phil. thesis at the University of Sussex. It struck me when I began the work for the thesis in the early 1980 s that it was rather odd that very little research had been carried out on the political responses to unemployment by the unemployed. There is still very little empirical research, and too much idle, illinformed speculation. Although unemployment, as it is officially measured, has fallen from the high levels of the early 1980s, it has, during the middle of 1990 , begun to rise again. I hope that what follows goes some way towards an understanding of political responses to unemployment both during the current period and in the past. I trust that the book will also be of some value to those interested in wider issues of social movements and contemporary social change.

Most of all, I would like to thank the many unemployed people who agreed to be interviewed for the the research reported in this book. Peter Saunders, my supervisor at Sussex, has provided endless encouragement and constant constructive criticism, not always heeded, throughout. I would like to thank the participants in several departmental and graduate student seminars in the Departments of Sociology at the Universities of Sussex and Lancaster who have commented on earlier versions of the work. Dan Shapiro, John Urry, Sylvia Walby and Alan Warde have commented on earlier drafts of several of the chapters below. The examiners of the original thesis, Huw Beynon and William Outhwaite, provided many detailed and useful comments. I would also like to thank Sue Penna and Kirk Mann for many detailed conversations about the content of what follows. Kirk Mann deserves special mention for having read no less than three versions of the text.

I am grateful to the staff of the libraries of the Universities of Sussex, Lancaster and Leeds for their assistance. The TUC and the Brighton centre for the unemployed were generous in providing documents upon which some of the analysis below is based. The Department of Sociology at the University of Lancaster kindly gave me an honorary research fellowship which enabled me to complete the writing up of the thesis from which this book has 
been developed. The departments at Lancaster and Leeds were also generous in the provision of printing facilities. The thesis and the book were written on an Atari ST using 1st Word Plus. I am especially grateful to the spelling checker! The research for the thesis, on which this book is based, was carried out with the aid of an ESRC research training studentship: number G00428222732.

Finally, I would like to thank the Department of Employment, Unemployment Benefits Section, for providing the means of existence during the last two months of the writing up of the thesis in the summer of 1988.

PAUl BAGguley

Department of Social Policy and Sociology

University of Leeds 


\section{List of Abbreviations}

$\begin{array}{ll}\text { CEP } & \text { Community Enterprise Programme } \\ \text { COHSE } & \text { Confederation of Health Service Employees } \\ \text { CP } & \text { Community Programme } \\ \text { CPAG } & \text { Child Poverty Action Group } \\ \text { DE } & \text { Department of Employment } \\ \text { DHSS } & \text { Department of Health and Social Security } \\ \text { ILP } & \text { Independent Labour Party } \\ \text { LRC } & \text { Labour Representation Committee } \\ \text { MC } & \text { Management Committee } \\ \text { MSC } & \text { Manpower Services Commission } \\ \text { NGSW } & \text { Not Genuinely Seeking Work } \\ \text { NUAAW } & \text { National Union of Agricultural and Allied Workers } \\ \text { NUPE } & \text { National Union of Public Employees } \\ \text { NUW(C)M } & \text { National Unemployed Workers (Committee) Move- } \\ \text { OECD } & \text { ment } \\ \text { PAC } & \text { Office of Economic Cooperation and Development } \\ \text { PC } & \text { Policy Committee } \\ \text { PER } & \text { Professional and Executive Recruitment } \\ \text { SDF } & \text { Social Democratic Federation } \\ \text { SERTUC } & \text { South East Regional Trade Union Congress } \\ \text { TC } & \text { Trades Council } \\ \text { TUC } & \text { Trades Union Congress } \\ \text { UAB } & \text { Unemployment Assistance Board } \\ \text { UWU } & \text { Unemployed Workers' Union } \\ \text { WEA } & \text { Workers' Education Association } \\ & \end{array}$

